ISSN 0854-9818

Oct 1995

\title{
Production and Standards for Chemical Non-Wood Forest Products in China
}

Shen Zhaobang

CENTER FOR INTERNATIONAL FORESTRY RESEARCH

office address: Jalan CIFOR, Situ Gede, Sindangbarang, Bogor 16680, Indonesia mailing address: P.O. Box 6596 JKPWB, Jakarta 10065, Indonesia tel.: +62 (251) 622622 fax: +62 (251) 622100

email: cifor@cgnet.com

$W W W:$ http://www.cgiar.org/cifor 


\section{The CGIAR System}

The Consultative Group on International Agricultural Research (CGIAR) is an informal association of 41 public and private sector donors that supports a network of sixteen international agricultural research institutes, CIFOR being the newest of these. The Group was established in 1971. The CGIAR Centers are part of a global agricultural research system which endeavour to apply international scientific capacity to solution of the problems of the world's disadvantaged people.

\section{CIFOR}

CIFOR was established under the CGIAR system in response to global concerns about the social, environmental and economic consequences of loss and degradation of forests. It operates through a series of highly decentralised partnerships with key institutions and/or individuals throughout the developing and industrialised worlds. The nature and duration of these partnerships are determined by the specific research problems being addressed. This research agenda is under constant review and is subject to change as the partners recognise new opportunities and problems. 


\section{Foreword}

China has a long tradition of Non-Wood Forest Product (NWFP) use. It constitutes the main producer, consumer and, frequently, exporter for a large number of these products. China has also maintained a high interest in research on different aspects of utilisation of NWFPs, including chemical uses. Yet, little is known outside the country about the production, processing, marketing and quality control of these products.

CIFOR has a strong interest in NWFPs as a means to manage the forest and to increase the wealth of the communities living close to it. Thus, in September 1994, just three months after my arrival in Indonesia, I travelled to China to develop the first contacts with Chinese researchers working on these issues.

Among other institutions, I visited the Research Institute of Chemical Processing and Utilization of Forest Products, Chinese Academy of Forestry, based in Nanjing. The achievements of the RICPUFP and the importance of chemical NWFPs in China convinced me of the need to share this information abroad. The Director of the Institute, Prof. Shen Zhaobang, agreed to prepare a synthesis of the production and quality standards for the main group of products. This publication is the fruit of that work.

CIFOR expects that the information on production, exports and technical specifications contained in this document will be useful to the scientific and development community interested in multiple use of forests. By making this publication available CIFOR also recognises the arduous work, not always in easy conditions, undertaken by our Chinese colleagues of the RICPUFP and the still untapped potential for new and additional developments based on NWFPs. 


\section{CONTENTS}

Introduction

Institutional Aspects

Products and Processes

Naval Stores 2

Gum Oleoresin 2

Rosin and Turpentine 4

Reprocessed Products of Gum Rosin 6

Reprocessed Products of Turpentine Oil 8

Research and Development of New Reprocessed 10

Products from Rosins and Turpentine

Plant Tannins

Chinese Gallnut

Forest Perfume Products $\quad 12$

Main Essential Oil Products $\quad 13$

Forest Medicinal and Health Products $\quad 14$

$\begin{array}{lr}\text { Conclusion and Prospects } & 16\end{array}$

$\begin{array}{ll}\text { References } & 16\end{array}$

$\begin{array}{lr}\text { Annex } 1 & 17\end{array}$

$\begin{array}{ll}\text { Annex } 2 & 18\end{array}$ 


\title{
Production and Standards for Chemical Non-Wood Forest Products in China
}

\author{
Shen Zhaobang ${ }^{1}$
}

\begin{abstract}
Summary
Non-wood forest products are an important part of the forestry industry in China, particularly in poor mountain and forest areas. This paper concentrates on the present situation of chemical uses for non-wood forest products in China. It outlines the status of traditional products such as rosin, turpentine, tannin extracts and shellac, as well as pharmaceutical and health products. More recent developments in extraction and processing are also discussed. The prospects for chemical non-wood forest product extraction and utilisation are explored in the local and international contexts as contributors to the overall welfare of the Chinese population.
\end{abstract}

\section{Introduction}

The forest products of China may be classified into three broad groups:

1. Mechanically processed products made from wood, such as roundwood, timber, plywood, particleboard and fibreboard.

2. Forest chemical products. In this category, there are two groups of products based on the raw material used. The first includes the wood chemical products, which are produced by chemical processing of woody raw material, such as logs, chips and sawdust. From a chemical perspective, this group is usually produced by utilisation of the three main constituents of wood - cellulose, hemicellulose and lignin. The important products of this group are pulp, paperboard, charcoal and active carbon.

The second group is non-wood forest chemical products, which are produced by chemical processing of non-wood forest resources, i.e. leaves, bark, oleoresin, fruits, seeds and flowers, as well as various undergrowth plants in forest areas. In this group of products some natural organic substances are found i.e. terpenoids, flavonoids, polyphenols, resin acids, etc. The main products of this group are gum rosin, turpentine, tannin extracts, tannic and gallic acids, shellac, various essential oils and biologically active substances for pharmaceutical preparations as well as a series of products developed by further processing. These products are widely used in the chemical, food, pharmaceutical and light industries.

3. Economic forest products. This group includes a number of traditional and special forest products, such as edible fungi, a variety of nuts, spices, oils, as well as bamboo and rattan.

Based on the definition proposed by FAO, the nonwood forest chemical products and the economic forest products, as describe above, will be referred to as nonwood forest products (NWFPs). This paper will concentrate on the present situation for chemical uses of NWFPs in China.

\section{Institutional Aspects}

Chemical utilisation of NWFPs has developed in China over many years. As well as the traditional forest chemical products, such as rosin, turpentine, tannin extracts and Chinese shellac, increased attention has been paid to the preparation of pharmaceutical and health products and other new products from non-wood forest resources. Aware that NWFPs usually are produced in poor mountain and forest areas, where natural products are sometimes the only resources for industrial uses, and that further chemical processing of NWFPs brings benefit to the local government and people, the Chinese Government encourages and supports the development of NWFPs in these areas. It provides low-interest loans,

\footnotetext{
1 Research Institute of Chemical Processing and Utilization of Forest Products, Chinese Academy of Forestry, Nanjing, People's Republic of China
} 
assists in establishment of raw material bases, formulates policy to protect resources, and supports the research and development of new products and technology. For example, a series of regulations for tapping pine resins and rosin production guarantees sustainable use and supply of these products.

In China, the production of non-wood forest chemical products is managed and controlled by the Industrial Department of the Ministry of Forestry (MOF). There are also some national corporations, such as the Chinese Corporation of Forestry Products Industry, the China Golden Dragon Rosin Group and the Chinese Association of Forest Products Industry, which are also responsible for market planning, production co-ordination and management.

The standards for chemical products are also managed by the Industrial Department and Scientific Technological Department in the MOF. Based on the proposals from enterprises, research institutions or local forest bureaux, the MOF arranges the setting of standards available. They usually are prepared by research institutes in co-operation with enterprises and consumers and, after evaluation and approval by a group of specialists organised by the MOF, the standard is finally issued for enforcement by the National Standard Bureau of the MOF. A special Quality Supervision and Inspection Station of Forest Chemical Products, Ministry of Forestry is established in the Research Institute of Chemical Processing and Utilization of Forest Products (RICPUFP) and accredited by the State Bureau of Technical Supervision to oversee the quality control of products.

A national institute, RICPUFP, of the Chinese Academy of Forestry includes an affiliated Design Institute of Forest Chemical Industry and a National Technical Centre of Forest Chemical Engineering, which have pilot study facilities. RICPUFP specialises in chemistry, chemical engineering of NWFPs and carries out the basic and applied research, development of new products and technology, as well as engineering design of plant in this field.

There are also faculties and departments of forest chemical products in some forestry universities in China. In addition to the role of the MOF, a number of institutions and corporations under the Ministry of Light Industry as well as those from local communities, are also working on the chemical utilisation of NWFPs, mainly in the field of pharmaceutical preparation, flavouring substances and health foods. According to Chinese regulations, new pharmaceutical preparations must be approved by the new medicine committee after a series of toxicological, pharmacological and clinical tests and the new food additives from NWFPs also need to be approved by the State Food Additive Committee.

\section{Products and Processes}

\section{Naval Stores}

Gum rosin and turpentine and their processed byproducts are the most important chemical products from non-wood forest resources in China. The naval stores industry in China is more than fifty years old. In 1936 , rosin output was 16,000 tons; today the production capacity for rosin in China is 700,000 tons per year, with the annual output of about 400,000 tons. This makes China the largest producer of gum rosin in the world.

\section{Gum Oleoresin}

\section{Resources}

Pine forests are widely distributed throughout China. About twenty species are used for oleoresin tapping; the main ones are Pinus massoniana, P. yunnanensis,

Table 1. Pine Resources in China

\begin{tabular}{lccccc}
\hline Provinces & $\begin{array}{c}\text { Pine Area } \\
\text { (mil ha) }\end{array}$ & $\begin{array}{c}\text { Growing Stock } \\
\left(\mathrm{mil} \mathrm{m}^{3}\right)\end{array}$ & $\begin{array}{c}\text { Pine area for } \\
\text { tapping } \\
(\text { mil ha) }\end{array}$ & $\begin{array}{c}\text { Proportion of } \\
\text { total area } \\
(\%)\end{array}$ & $\begin{array}{c}\text { Trees for } \\
\text { tapping } \\
\text { (mil trees) }\end{array}$ \\
\hline Guangxi & 3.24 & 194 & 0.48 & 15 & 90 \\
Guangdong & 1.25 & 75 & 0.22 & 17 & 40 \\
Fujian & 1.53 & 104 & 0.12 & 7.7 & 22 \\
Hubei & 2.13 & 57.48 & 0.86 & 3.9 & 11 \\
Yunnan & 4.00 & 370 & 2.00 & 50.0 & - \\
Hunan & 1.64 & 36.8 & 0.05 & 3.1 & 9.5 \\
\hline
\end{tabular}


P. latteri, P. tabulaeformis and P. elliottii. The major production areas are located in the southern part of China, namely Guangdong, Guangxi, Yunnan, Fujian, Jiangxi, Hunan and Sichuan provinces. The total area of pine forest is 13 million ha with growing stock of about 800 million $\mathrm{m}^{3}$.

The annual capacity for production of oleoresin is approximately 1.5 million tons, if all available resources are used. At present the annual output in China is about 500,000 tons, equivalent to only one-third of the possible output. Production increased by about 36 per cent between 1971 and 1989 (Figure 1).

The chemical composition of oleoresin from the main Chinese pine species appears in Table 2.

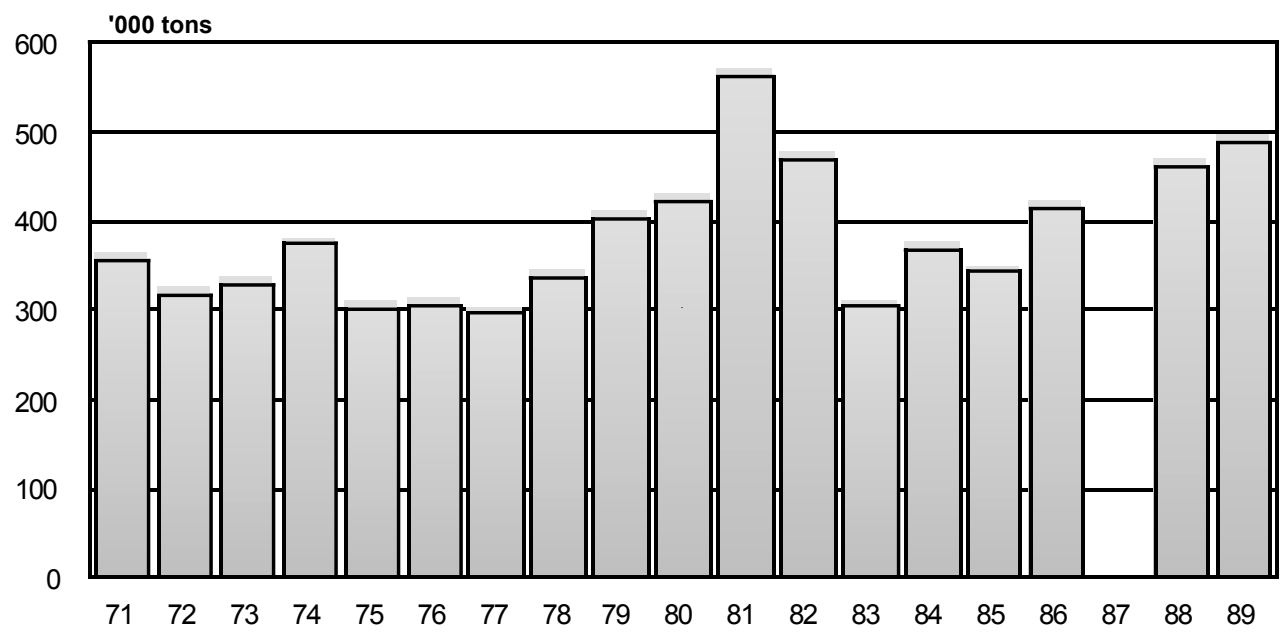

Figure 1. Gum Oleoresin Output in China, 1971 - 1989

Table 2. Chemical Composition of Oleoresins from Chinese Pine Species (\%)

\begin{tabular}{llccccc}
\hline Species & 1 & 2 & 3 & 4 & 5 & 6 \\
\hline a-Pinene & 31.7 & 37.4 & 38.8 & 38.5 & 15.2 & 21.8 \\
Camphene & 0.5 & 0.3 & 0.4 & 0.5 & 0.3 & 0.3 \\
b-Pinene & 1.2 & 0.3 & 0.4 & 2.0 & 12.4 & 2.3 \\
Myrcene & 0.4 & 0.2 & 0.5 & 0.5 & 0.4 & 0.6 \\
Dipentene & 0.5 & 0.2 & 0.5 & 1.7 & 3.2 & 0.8 \\
a-Terpinene & $\operatorname{tr}$ & 0.1 & 0.1 & 0.1 & $\operatorname{tr}$ & 0.1 \\
Longifolene & 9.5 & - & 2.1 & - & - & 1.7 \\
Cargophyllene trans-b & 1.4 & $\operatorname{tr}$ & $\operatorname{tr}$ & $\operatorname{tr}$ & - & 0.3 \\
Farnesene & 0.5 & 0.3 & 0.1 & 0.1 & - & 0.2 \\
8,15 Isopimaric acid & 0.1 & 0.1 & 0.1 & 0.1 & 0.1 & 1.0 \\
Pimaric acid & 0.1 & 0.3 & 0.2 & 0.7 & 0.9 & 0.4 \\
Communic acid & 4.1 & 0.1 & 4.1 & 2.9 & 2.8 & 2.6 \\
Sandaracopimaric acid & 1.3 & 3.7 & 1.2 & 1.4 & 3.8 & 1.3 \\
Isopimaric acid & 0.2 & 10.9 & 1.1 & 1.4 & 11.2 & 14.0 \\
Palustric \& levopimaric acid & 21.5 & 24.3 & 28.5 & 31.0 & 26.0 & 7.7 \\
Dehydroabietic acid & 1.7 & 1.2 & 2.7 & 2.6 & 2.05 & 0.7 \\
Abietic acid & 10.9 & 8.2 & 8.2 & 5.5 & 4.7 & 20.1 \\
Neoabietic acid & 9.9 & 2.7 & 8.5 & 8.7 & 11.3 & 4.2 \\
Mercusic acid & - & 8.2 & - & - & - & - \\
\hline
\end{tabular}

\section{P. massoniana}

4. P. yunnanensis
2. P. latteri

5. P. elliottii
3. P. kesiya var. langbianensis

6. P. armandi 


\section{Tapping Technology}

Except in some districts in Guangdong, Guangxi and Fujian provinces, gum oleoresin tapping in China is mainly by traditional methods without the use of stimulants. Only the trees of diameter $\geq 20 \mathrm{~cm}$ can be tapped. One worker can tap about 600 trees per year with an annual output of 1.5 - 2 tons. The season for gathering the oleoresin in China is between May and November. China has low productivity compared with many countries, caused by (i) delayed extension of new technology and (ii) the pine resources, currently used for tapping in China, are mainly natural secondary forest where the number of trees per unit area is much less than that in plantations. About 250,000 farmers or tapping workers are engaged in gum oleoresin tapping in China per year. The total income of tapping workers amounts to 700 million yuan.

\section{Rosin and Turpentine}

\section{General Situation}

China's gum rosin production has expanded over the past forty years to reach 430,000 tons in 1993 (Figure $2)$. It is the largest producer in the world.

More than 90 per cent of rosin production in China comes from the southern provinces of Guangdong, Guangxi, Fujian, Yunnan and Jiangxi. The turpentine output is directly related to that of oleoresin and rosin.

The output of turpentine in China in recent years is listed in Table 3. The amount of rosin exported is about half of the total production, reaching 277,000 tons in 1993 (Figure 3).

Domestic consumption of gum rosin is 170,000 200,000 tons annually. Different industries use gum rosin in varying amounts (Figure 4).

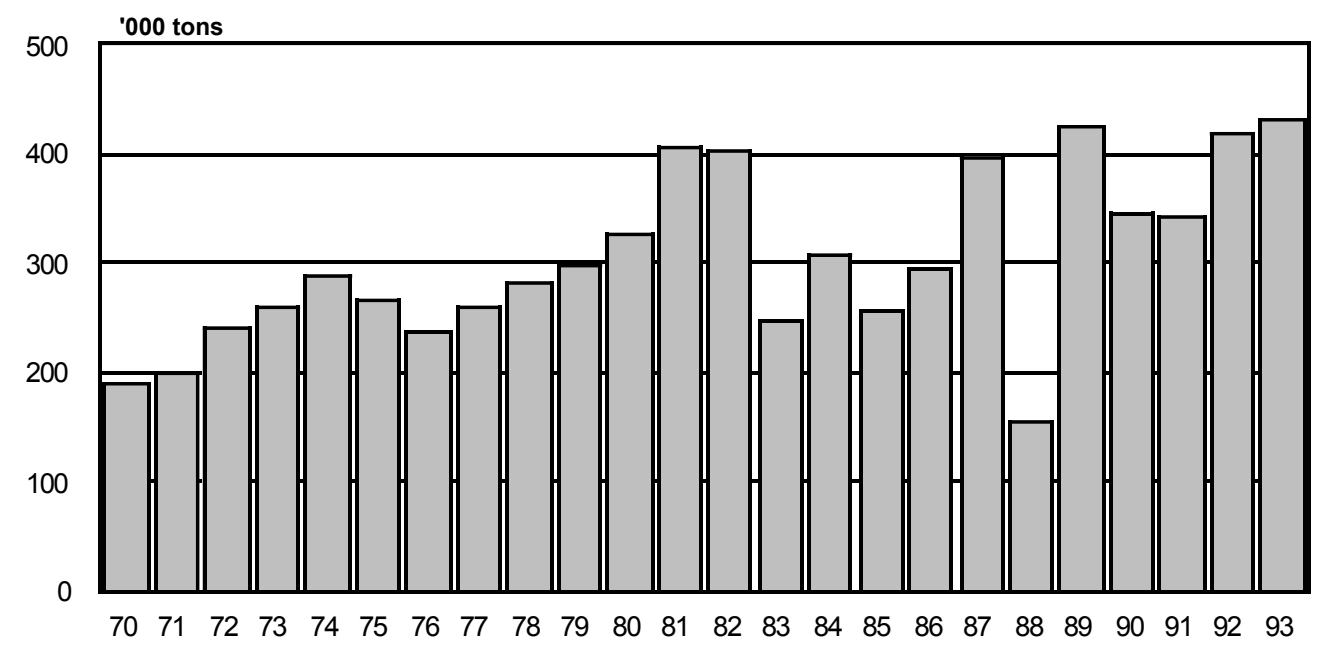

Figure 2. Annual Output of Gum Rosin in China, 1970 - 1993

Table 3. Turpentine Output in China (in Tons)

\begin{tabular}{lccc}
\hline & 1989 & 1990 & 1991 \\
\hline Guangdong & 16,021 & 11,617 & 10,034 \\
Guangxi & 15,844 & 11,571 & 15,529 \\
Fujian & 13,013 & 12,574 & 11,959 \\
Others & 12,371 & 11,247 & 12,439 \\
Total & $\mathbf{5 7 , 2 4 9}$ & $\mathbf{4 7 , 0 0 9}$ & $\mathbf{4 9 , 9 6 1}$ \\
\hline
\end{tabular}




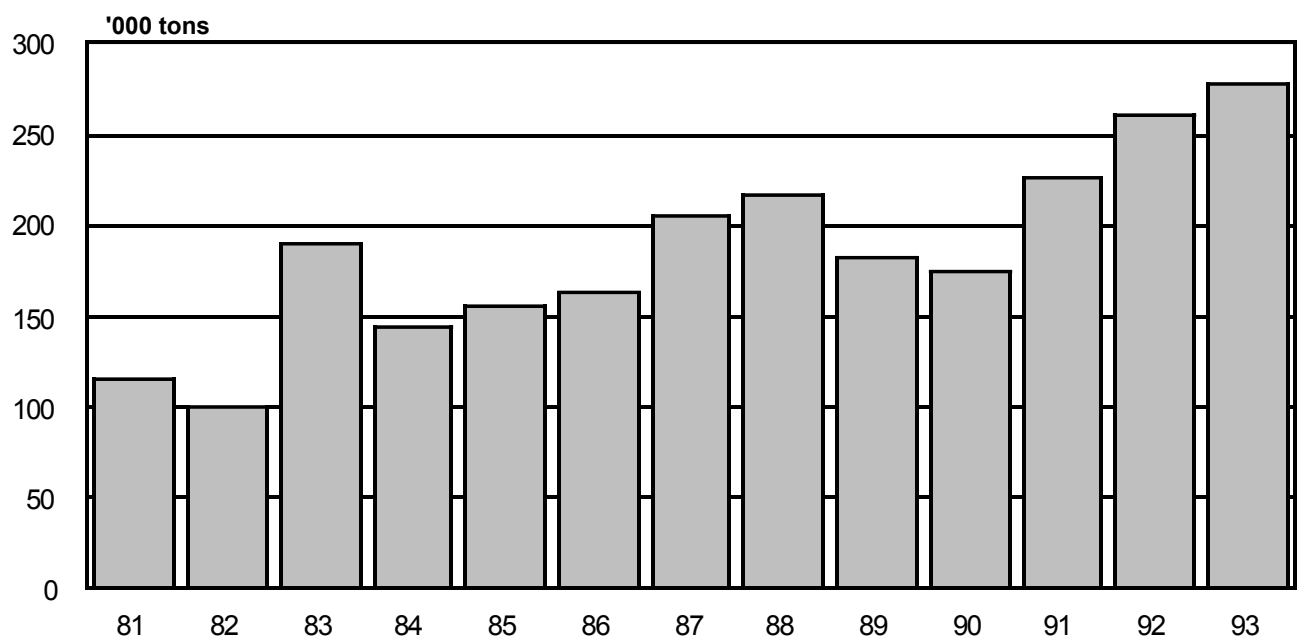

Figure 3. Export of Gum Rosin, $1981-1993$

\section{Production Technology and Product Quality}

Gum oleoresin processing is mainly by the steam distillation process. The batch process is suitable for plant with annual capacity of 1,000 - 2,000 tons, and the continuous process is used for plant with capacity of more than 3,000 tons rosin per year.

The main steps of the process are melting, precipitation and steam distillation. The crude oleoresin is heated with direct steam to $95^{\circ} \mathrm{C}$ and the melted resin solution is purified by precipitation and washing with water to remove various impurities. It is then distilled in a distillation pot or column. From the top and bottom of the column respectively, the turpentine oil and rosin are obtained. The rosin is composed of about 88 per cent resin acids, 4 per cent fatty acids and some neutral substances. The composition of resin acids in rosins from main Chinese pine species is listed in Table 4.

The Chinese national standards for rosin (GB 8145 - 87) and turpentine (GB 12901 - 91) are shown in Tables 5 and 6.

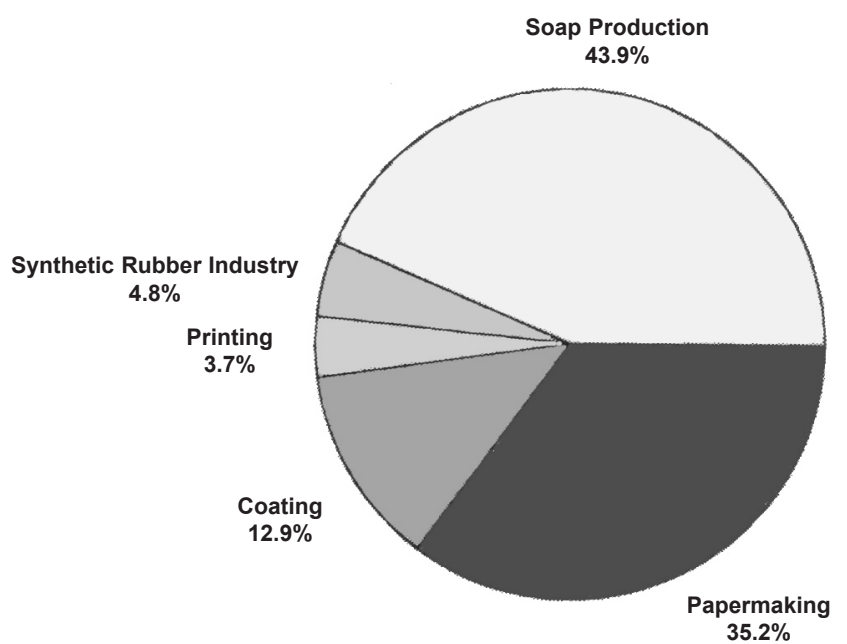

Figure 4. Industrial Uses of Gum Rosin

Table 4. Composition of Resin Acids in Rosins from Different Pine Species (\%)

\begin{tabular}{lcccccccc}
\hline Acid & 1 & 2 & 3 & 4 & 5 & 6 & 7 & 8 \\
\hline P. massoniana & 34.2 & 36.6 & 13.6 & 5.0 & 8.8 & 0.0 & 1.9 & 0.0 \\
P. yunnanensis & 21.9 & 46.7 & 12.6 & 5.5 & 6.0 & 5.8 & 2.1 & 0.0 \\
P. kesiya & 27.1 & 37.3 & 13.7 & 8.6 & 7.4 & 3.8 & 2.2 & 0.0 \\
P. latteri & 19.7 & 28.4 & 5.1 & 5.6 & 0.0 & 15.4 & 7.4 & 18.5 \\
P. elliottii & 18.2 & 26.9 & 13.3 & 9.1 & 4.3 & 24.0 & 3.8 & 0.0 \\
\hline
\end{tabular}
1. Palustric
2. Abietic
3. Neoabietic
5. Pimaric
6. Isopimaric
7. Sandaracopimaric
4. Dehydroabietic
8. Mercusic 
Table 5. Technical Specifications of Gum Rosin (GB 8145 - 87)

\begin{tabular}{|c|c|c|c|c|c|c|}
\hline Grade & Super & I & II & III & IV & $\mathrm{V}$ \\
\hline Appearance & \multicolumn{2}{|c|}{ transparent } & \multicolumn{2}{|c|}{ transparent } & \multicolumn{2}{|c|}{ transparent } \\
\hline Colour & $\begin{array}{l}\text { slight- } \\
\text { yellow }\end{array}$ & $\begin{array}{l}\text { pale- } \\
\text { yellow }\end{array}$ & yellow & $\begin{array}{l}\text { deep- } \\
\text { yellow }\end{array}$ & $\begin{array}{l}\text { yellow- } \\
\text { brown }\end{array}$ & $\begin{array}{c}\text { yellow- } \\
\text { red }\end{array}$ \\
\hline Softening point ${ }^{\circ} \mathrm{C}(\mathrm{H} \& \mathrm{G})$ & $\geq$ & 76 & \multicolumn{2}{|c|}{75} & \multicolumn{2}{|c|}{74} \\
\hline Acid No.mgKOH/g & $\geq$ & 116 & \multicolumn{2}{|c|}{165} & \multicolumn{2}{|c|}{164} \\
\hline Unsaponifiable matter \% & $\leq$ & 5 & \multicolumn{2}{|c|}{5} & \multicolumn{2}{|c|}{6.5} \\
\hline Alcohol insoluble \% & $\leq$ & 0.03 & \multicolumn{2}{|c|}{0.03} & \multicolumn{2}{|c|}{0.04} \\
\hline Ash \% & $\leq$ & 0.02 & \multicolumn{2}{|c|}{0.03} & \multicolumn{2}{|c|}{0.04} \\
\hline
\end{tabular}

Table 6. Technical Specifications of Turpentine (GB 12901 - 91)

\begin{tabular}{|c|c|c|c|}
\hline Grade & Super grade & First grade & Second grade \\
\hline $\begin{array}{l}\text { Appearance } \\
\text { Colour }\end{array}$ & \multicolumn{3}{|c|}{$\begin{array}{l}\text { transparent, no water, no impurities, and no suspension by } \\
\text { comparison with standard solution }\end{array}$} \\
\hline Relative density $\mathrm{d}_{4} 20$ & $<\quad 0.870$ & 0.880 & 0.940 \\
\hline Index of refraction $\mathrm{n}^{20}$ & $1.465-1.471$ & $1.467-1.478$ & 1.510 \\
\hline Start of distillation ${ }^{\circ} \mathrm{C}$ & 150 & 150 & - \\
\hline $\begin{array}{l}\text { Volume of distillate up to } 170^{\circ} \mathrm{C} \% \geq \\
\text { Acid No.mgKOH/g }\end{array}$ & $\begin{array}{l}90 \\
0.5\end{array}$ & $\begin{array}{l}85 \\
1.0\end{array}$ & - \\
\hline
\end{tabular}

\section{Reprocessed Products of Gum Rosin}

Reprocessed products of gum rosin mainly include modified rosins and rosin derivatives. More than forty reprocessed products have been developed and commercialised in China. At present the main processed rosin products are hydrogenated rosin, rosin amine, rosin soaps and rosin sizing agents for paper making. The total output of reprocessed rosin products accounts for 8 per cent of rosin produced in China and is about 30,000 tons per year. To develop new reprocessed products of rosin and to expand their uses in various industries are important development directions of the industry in China. According to the national plan, reprocessed rosin products will make up about 25 per cent of the total output of rosin in China by the end of the twentieth century. The characteristics of the main products are described below.

\section{Modified Rosin}

Hydrogenated Rosin. Hydrogenated rosin is an amorphous transparent solid resin with a light colour and has high oxygen-resistant properties. It is widely used in the adhesive industry to increase the adhesion of the hot-melting, pressure-sensitive and other adhesives and is also used in the food, solder and pharmaceutical industries.

Abietic type resin acids in gum rosin are partly hydrogenated under pressure $13 \mathrm{Mpa}$ and temperature $220-250^{\circ} \mathrm{C}$ with $\mathrm{Pd} / \mathrm{C}$ catalyst to obtain the hydrogenated rosin. A continuous hydrogenation process has been developed in China. The annual output of hydrogenated rosin in China is 1,500 tons of which about one-half is exported. The quality standards of hydrogenated rosin are listed in Table 7.

Disproportionated Rosin. The gum rosin is processed under high temperature with $\mathrm{Pd} / \mathrm{C}$ catalyst to obtain the disproportionated rosin, as well as a mixture of dehydro-, dihydro- and tetra-hydroabietic acids. The disproportionated rosin is mainly used as an emulsifier for the synthetic rubber industry. The quality standards for disproportionated rosin are shown in Table 8. 
Table 7. Technical Specifications of Hydrogenated Rosin (GB/T 14020 - 92))

\begin{tabular}{lcccc}
\hline Grade & & Super grade & First grade & Second grade \\
\hline Appearance & & transparent & transparent & transparent \\
Colour & & super & I & I \\
Abietic acid $\%$ & 2.0 & 10 & 2.5 & 3.0 \\
Dehydroabietic acid \% & $\leq$ & 10 & 71 & 15 \\
Softening point $(\mathrm{H} \& \mathrm{G}){ }^{\circ} \mathrm{C}$ & $\geq$ & 72 & 160 & 70 \\
Acid No.mgKOH/g & $\geq$ & 162 & 0.03 & 158 \\
Impurities & $\leq$ & 0.03 & 0.2 & 0.04 \\
Oxygen absorbed \% & $\leq$ & 0.2 & 8.0 & 0.3 \\
Unsaponifiable matters & $\leq$ & 7.0 & & 9.0 \\
\hline
\end{tabular}

Table 8. Technical Specifications of Disproportionated Rosin (ZBB 72002-84)

\begin{tabular}{lccc}
\hline Grade & & Super grade & First grade \\
\hline Colour, no deeper than & & 1 & 3 \\
Abietic acid \% & $\leq$ & 0.2 & 0.5 \\
Dehydroabietic acid \% & $\geq$ & 52.0 & 45.0 \\
Softening point $(\mathrm{H} \mathrm{\& G})^{\circ} \mathrm{C}$ & $\geq$ & 75.0 & 75.0 \\
Acid No. mgKHO/g & $\geq$ & 155.0 & 150.0 \\
Unsaponifiable matter & $\leq$ & 10.0 & 12.0 \\
\hline
\end{tabular}

Maleated Rosin. Maleated rosin is an adduct of rosin with maleic anhydride, and its main component is maleated pimaric acid. There are two grades of maleated rosin with a different content of maleated anhydride. The quality standards for maleated rosin (ZB B 72001 - 84) are shown in Table 9.

The most important use for maleated rosin is as a sizing agent in the paper-making industry. It is also used in painting, ink and other chemical industries.
Polymerised Rosin. Polymerised rosin is produced by polymerisation of abietic-type resin acids in gum rosin with acid catalysts. The main component of polymerised rosin is dimeric resin acid $(\mathrm{C} 40 \mathrm{H} 60 \mathrm{O} 4)$. Polymerised rosin possesses a high softening point, good resistance to oxygenation and mix well with other synthetic resins. It is widely used in printing ink and coating industries. The quality standards of polymerised rosin (ZB B 72008 - 89) is listed in Table 10.

Table 9. Technical Specifications of Maleated Rosin (ZBB 72001 - 84)

\begin{tabular}{lrcc}
\hline Grade & \multicolumn{2}{c}{115} & 103 \\
\hline Appearance & \multicolumn{2}{c}{ transparent } \\
Colour & \multicolumn{2}{c}{ red-brown } & yellow-red \\
Softening point $(\mathrm{H} \mathrm{\& G}){ }^{\circ} \mathrm{C}$ & $\geq$ & 106 & 84 \\
Acid No. mgKHO/g & $\geq$ & 220 & 178 \\
Saponification No.mgKOH/g & $\geq$ & 280 & 190 \\
Maleic anhydride adduct \% & $\geq$ & 47 & 10 \\
Impurities \% & $\leq$ & 0.06 & 0.06 \\
\hline
\end{tabular}


Table 10. Technical Specifications of Polymerised Rosin (ZBB 72008 - 89)

\begin{tabular}{lccc}
\hline Grade & & 115 & 140 \\
\hline Appearance & & \multicolumn{3}{c}{ transparent } \\
Colour & $\leq$ & 3 & 3 \\
Softening point $(\mathrm{H} \mathrm{\& G}){ }^{\circ} \mathrm{C}$ & $\geq$ & $110-120$ & $135-145$ \\
Alcohol insoluble \% & $\leq$ & 0.03 & 0.03 \\
Acid No. mgKHO/g & $\geq$ & 145.0 & 140.0 \\
Soluble in hot water \% & $\leq$ & 0.20 & 0.20 \\
\hline
\end{tabular}

\section{Rosin Derivatives}

Rosin Acid Salts. The carboxylic group of resin acids can be combined with different metallic ions to get resin acid salts. Main products of this group in China are sodium, potassium, calcium soaps of rosin and modified rosin, such as disproportionated rosin and potassium soap.

Rosin Resins. A series of products are manufactured in China by esterification of rosin and various modifier rosins with different alcohols. The most important rosin resins and their technical specifications are listed in Table 11.

The rosin esters are widely used in printing ink, coating industries and as tackifier for various type of adhesives. Some of them are approved for application in food industries, e.g., the glycerolester of rosin and glycerol ester of partially hydrogenated rosin are used in the soft drink and other food industries.

\section{Reprocessed Products of Turpentine Oil}

The main components ( 90 per cent) of Chinese turpentine are apinene and $\mathrm{b}$-pinene. In turpentine oil from P. massoniana, the main pine species for oleoresin tapping in China, the a-pinene content is as high as 90 per cent. The main reprocessed products of turpentine oil in China are based on utilisation of a-pinene, namely, camphor, turpineol, borneol and terpene resins. The annual output of these products is about 20,000 tons.

Table 11. Technical Specifications of Rosin Resins

\begin{tabular}{lcccc}
\hline & $\begin{array}{c}\text { Colour } \\
\text { Rosins }\end{array}$ & $\begin{array}{c}\text { Softening } \\
\text { (Gardner) }\end{array}$ & $\begin{array}{c}\text { Acid No. } \\
\text { Point } \\
(\mathrm{R} \& \mathrm{D})^{\circ} \mathrm{C}\end{array}$ & $\begin{array}{c}\text { Solubility } \\
\text { (benzene: }\end{array}$ \\
& & resin) $1: 1$ \\
\hline
\end{tabular}

\begin{tabular}{|c|c|c|c|c|c|}
\hline Methylester of rosin & $\leq$ & 3 & viscous liquid & $\leq$ & 10 \\
\hline Glycerolester of rosin & $\leq$ & 10 & $\geq 85$ & $\leq$ & 10 \\
\hline Diethyleneglycolester of rosin & $\leq$ & 7 & $35-40$ & $\leq$ & 10 \\
\hline PE ester of rosin & $\leq$ & 10 & $\geq \quad 100$ & $\leq$ & 20 \\
\hline Methylester of hydrogenated rosin & $\leq$ & 2 & viscous liquid & $\leq$ & 10 \\
\hline Diethyleneglycolester of hydrogenated rosin & $\leq$ & 8 & $30-40$ & $\leq$ & 15 \\
\hline Glycerolester of polymerized rosin & $\leq$ & 11 & 120 & $\leq$ & 10 \\
\hline Glycerolester of hydrogenated rosin & $\leq$ & 8 & 78 & $\leq$ & 10 \\
\hline PE ester of hydrogenated rosin & $\bar{s}$ & 8 & 95 & $\bar{s}$ & 20 \\
\hline PE ester of polymerized rosin & $\bar{s}$ & 12 & 130 & $\bar{s}$ & 20 \\
\hline Glycerolester of maleated rosin & $\bar{s}$ & 10 & 130 & $\bar{s}$ & 30 \\
\hline Glycerolester of disproportionated rosin & $\bar{s}$ & 8 & 80 & $\overline{\leq}$ & 10 \\
\hline
\end{tabular}

* The Gardner colour system is scaled from 2-18 and 18 is the darkest 
Table 12. Technical Specifications of Synthetic Camphor (GB 4895 - 91)

\begin{tabular}{|c|c|c|c|c|}
\hline Grade & & Super grade & First grade & Second grade \\
\hline Appearance & \multicolumn{4}{|c|}{ White powdery crystals } \\
\hline Water & \multicolumn{4}{|c|}{$\begin{array}{c}10 \%(\mathrm{w} / \mathrm{V}) \text { petroleum-ether solution should be clean } \\
\text { and transparent }\end{array}$} \\
\hline Non-volatile substances $\%$ & $\leq$ & 0.05 & 0.05 & 0.10 \\
\hline Alcohol insoluble \% & $\bar{s}$ & 0.01 & 0.01 & 0.015 \\
\hline Melting point ${ }^{\circ} \mathrm{C}$ & $\leq$ & 170 & 168 & 165 \\
\hline Content $\%$ & $\geq$ & 96 & 96 & 94 \\
\hline $\begin{array}{l}\text { Colouration with } \mathrm{H}_{2} \mathrm{SO}_{4} \text {, no } \\
\text { deeper than standard iodine } \\
\text { solution }\end{array}$ & $\leq$ & $1 / 1000$ & $1 / 1000$ & 1 \\
\hline
\end{tabular}

\section{Synthetic Camphor}

The camphor, synthesised from pinene, is a mixture of rotation isomers, but the natural camphor is a laevorotatory compound. The quality standards of synthetic camphor (GB 4895 - 91) are shown in Table 12.

To produce camphor, the turpentine oil is first distilled to obtain the pinene fraction, which is isomerised to camphene, under catalyst. The camphene, further purified by distillation under vacuum, is esterified with formic or acetic acid to obtain a methyl or ethyl ester of isoborneate. The ester, after purification, is saponified with $\mathrm{NaOH}$ solution to produce isoborneol, which is further dehydrogenated under the effect of a catalyst. The camphor is further purified by sublimation.
Camphor is mainly used for the production of celluloid and in the pharmaceutical industry. The annual output of synthetic camphor in China was 6,683 tons in 1990, 5,991 tons in 1991 and 5,716 tons in 1992 . Eighty percent is for export.

\section{Terpineol and Pine oil}

Terpineol, synthesised from turpentine oil, is a mixture of the series of monocycle-monoterpineols, mainly composed of a-terpineol. The production technology of terpineol includes two steps. The first step is hydration of pinene to obtain hydrated terpine, which is then dehydrated to obtain terpineol. The quality standards of terpineol are shown in Table 13.

Table 13. Technical Specifications of Terpineol

\begin{tabular}{|c|c|c|}
\hline Grade & Perfume grade & First grade \\
\hline $\begin{array}{l}\text { Colour \& state } \\
\text { Fragrance }\end{array}$ & $\begin{array}{l}\text { colourless thick liquid } \\
\text { like the fragrance of syringa }\end{array}$ & $\begin{array}{l}\text { colourless thick liquid } \\
\text { like the fragrance of syringa }\end{array}$ \\
\hline Density & $\mathrm{d}_{4}{ }^{20} 0.931-0.9375$ & $\mathrm{~d}_{4}{ }^{15} 0.936-0.941$ \\
\hline Refraction Index $20^{\circ} \mathrm{C}$ & $1.4825-1.4850$ & $1.4825-1.4850$ \\
\hline Fraction in $214-224^{\circ} \mathrm{C}$ & $\geq 96 \%$ of total volume & $\geq 90 \%$ of total volume \\
\hline Rotation & & $-0^{\circ} 10^{\prime} /+0^{\circ} 10^{\prime}$ \\
\hline Solubility & $\begin{array}{l}\text { soluble in } 70 \% \text { EtOH } \\
\text { (two times volume) }\end{array}$ & $\begin{array}{l}\text { soluble in } 5 \% \text { EtOH } \\
\text { (eight times volume) }\end{array}$ \\
\hline Flash point & $91^{\circ} \mathrm{C}$ & $91^{\circ} \mathrm{C}$ \\
\hline
\end{tabular}


Table 14. Technical Specifications of Polyterpene Resins (ZB B 72002 - 88)

\begin{tabular}{lcccc}
\hline Grade & & Super grade & First grade & Second grade \\
\hline Softening point $(\mathrm{H} \& \mathrm{G}){ }^{\circ} \mathrm{C}$ & $\geq$ & $80-120^{\circ} \mathrm{C}$ & $80-120^{\circ} \mathrm{C}$ & $80-120^{\circ} \mathrm{C}$ \\
Colour (Fe-Co) & $\leq$ & 6 & 8 & 10 \\
Acid No.mgKOH/g & $\leq$ & 1.0 & 1.0 & 1.0 \\
Saponification No.mgKOH/g & $\leq$ & 1.5 & 1.5 & 1.5 \\
Iodine value & & $40-75$ & $40-75$ & $40-75$ \\
Toluene insoluble $\%$ & $\leq$ & 0.05 & 0.05 & 0.05 \\
\hline
\end{tabular}

The terpineol is used for the preparation of perfurme for soap cosmetics. "Pine oil" is the product containing 50 - 80 per cent terpineol which is used as a dyeing agent, flotation oil and insecticide. The annual output of terpineol, including pine oil, in China is about 10,000 tons.

\section{Polyterpene Resin}

Polyterpene resins are a group of resins manufactured by the polymerisation of terpenes. Generally, there are four types of terpene resins, namely, poly-a-pinene, polyb-pinene, polylimonene resin and other polymers of terpenes. In China the major polyterpene resin produced is poly-a-pinene resin (5,000 tons per year). The polymerisation reaction is conducted with a catalyst under room or lower temperatures using toluene or dimethylbenzene as a solvent. By regulation of the catalyst composition, polymerisation temperature and the final product distillation conditions, resin with different softening points $\left(80-120^{\circ} \mathrm{C}\right)$ can be produced. The quality standards of poly-a-pinene resin are given in Table 14.

Polyterpene resins usually are pale-yellow transparent solids, easily soluble in benzene, toluene, turpentine oil and other organic solvents. These resins are mainly used as tackifiers for various type of adhesives and in printing ink and coating industries.

\section{Research and Development of New Reprocessed Products from Rosins and Turpentine}

Research in this area in China is concentrated on the development of new processes and products from rosin and turpentine. The major new achievements and research topics include:

* Synthesis of rosin-hydrocarbon resins;

* Preparation of rigid polyurethane foam, using maleopimaric acid esters, synthesised from rosin as polyol component;
* Synthesis of heat-resistant PVC cable plasticiser from maleopimaric acid;

* Preparation of terpene-phenolic resin;

* Preparation of serial products of rosin and modifier rosin emulsions;

* Preparation of colourless rosin and rosin resins;

* Synthesis of geraniol, nerol perillyl alcohol and other flavouring compounds from b-pinene;

* Preparation of b-pinene resins and dipentene resins;

* Synthesis of linalool, synthetic sandal, and other flavouring compounds from b-pinene;

* New processing technology for modified rosin and rosin esters; and

* Preparation of surfactants from rosin derivatives.

One of the main research directions for Chinese scientists is on the basis of abundant resources of Chinese gum oleoresin, to synthesise new, fine chemical products from its components, such as resin acids, a-pinene, b-pinene, etc. These fine chemicals will compete with some petro-chemical products and expand the uses of oleoresin products, thus bringing more economic benefits to the local farmers in forest areas of China.

\section{Plant Tannins}

Plant tannins are complex, higher-plant secondary metabolites of a polyphenol nature. They are water soluble and have the ability to precipitate some alkaloids, gelatin and proteins from solutions. The commercialised products of vegetable tannins in China are tannin extracts, tannic acid and gallic acid as well as their by-products.

\section{Tannin Extracts}

Tannin extracts have previously been one of the important non-wood forest chemical products, with output reaching more than 50,000 tons in 1987 . Since then, 
market demand has decreased and output has correspondingly declined (Figure 5).

The estimated output of tannin extract in 1992 and 1993 was about 15,000 tons. As the Chinese leather industry has developed, the deep-colour tannin extract produced from valonea and larch bark is required less, but demand for the light-colour tannin extracts, produced from Acacia mearnsii (black wattle), Myrica rubra and Phyllanthus emblica has grown. Market demand could not be met because of a lack of raw materials to produce the light-coloured extracts. Several thousands tons of high quality tannin extracts are imported annually. Hence, the Chinese Government has paid particular attention to plantations of $A$. mearnsii, which is introduced from Australia. The area of $A$. mearnsii forest is about 30,000 ha.

The raw materials used for tannin extract production in China include:
* Shell of Quercus acutissima. Tannin content 18 $33 \%$

* Bark of Myrica rubra.. Tannin content $15-28 \%$

* Bark of Phyllanthus emblica. Tannin content 21 $33 \%$

* Bark of Larix gmelini. Tannin content 6 - $18 \%$

* Bark of Acacia mearnsii. Tannin content 36-45 \%

The tannin extract is produced by water extraction. The raw material usually first is crushed, ground or cut to small pieces, followed by extraction using hot water. In the batch process, stationary extractors are used and in the continuous process, horizontal rotary extractors are used. After filtration, the water solution is evaporated under vacuum. The concentrated solution then is dried in a spray drier to produce a pulverised product. The quality standards of Chinese tannins extracts are shown in Table 15.

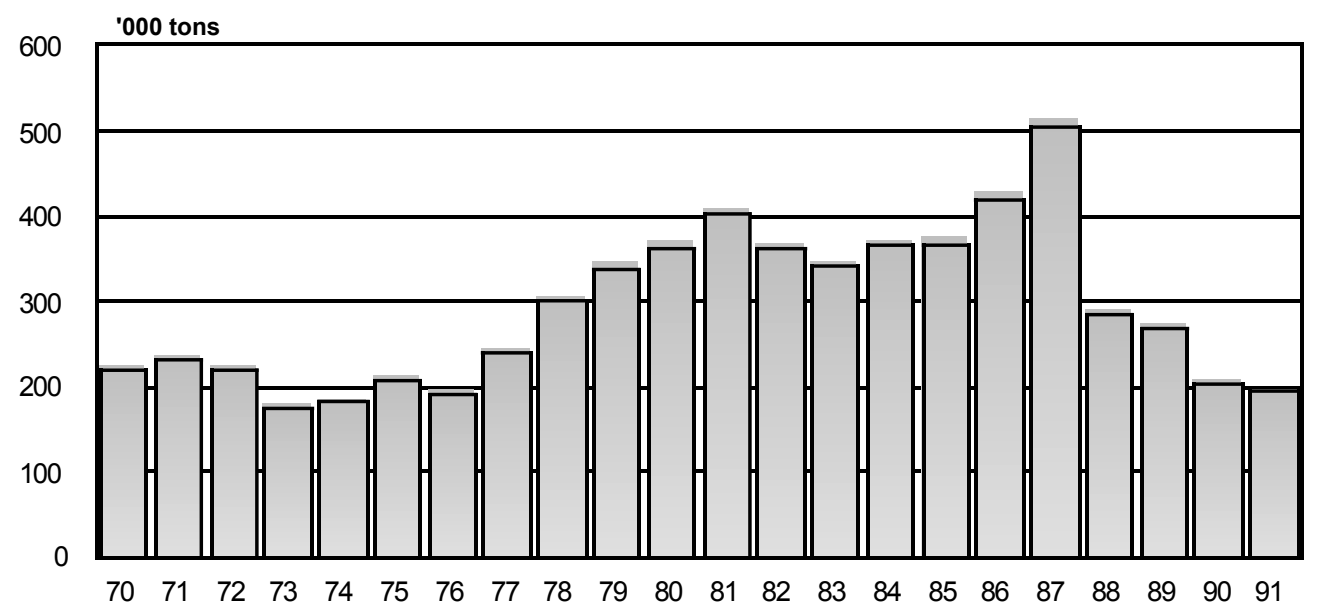

Figure 5. Annual Output of Tannin Extract, 1970 - 1991

Table 15. Technical Specifications of Some Chinese Tannin Extracts

\begin{tabular}{lcccc}
\hline Raw Material & $\begin{array}{c}\text { L. gmelini } \\
\text { bark }\end{array}$ & $\begin{array}{c}\text { A. mearnsii } \\
\text { bark }\end{array}$ & $\begin{array}{c}\text { Q. acutissima } \\
\text { shell }\end{array}$ & $\begin{array}{c}\text { M. rubra } \\
\text { bark }\end{array}$ \\
\hline Tannins \% & $\geq 59$ & 73 & 68 & 70 \\
Non-tannins \% & $\leq 31$ & 24 & 30 & 26 \\
Insoluble \% & $\leq 4$ & 2.5 & 2 & 4 \\
Water content \% & $\leq 12$ & 12 & 12 & 12 \\
Colour grade & 43 & 8 & 14 & 12 \\
Red & 23 & 2 & 4 & 4 \\
Yellow & 20 & 6 & 10 & 8 \\
Precipitate \% & 3 & 1.5 & 2 & 2 \\
pH & $4.5-5.5$ & $4.5-5.5$ & $3.5-4.2$ & $4.5-5.5$ \\
Standard & GB2620-81 & Under inspection & GB2616-81 & GB2617-81
\end{tabular}


Table 16. Technical Specifications of Tannic Acid for Industrial Use (GB 5308-85)

\begin{tabular}{lccc}
\hline Grade & I & II & III \\
\hline Tannic acid content \% & $\geq 81.0$ & 78.0 & 75.0 \\
Loss in drying \% & $\leq 9.0$ & 9.0 & 9.0 \\
Water insoluble \% & $\leq 0.6$ & 0.8 & 1.0 \\
Total colour (lovibond) & $\leq 2.0$ & 3.0 & 4.0 \\
\hline
\end{tabular}

\section{Chinese Gallnut}

Chinese gallnut is a traditional forest special product which is formed by various gallfly on the leaves of genus Rhus (Anacardiaceae), such as $R$. chinensis, $R$. potaninii and $R$. punjabensis var. sinica. Based on the variety of gallfly, 14 gallnuts can be classified, the major ones are horngall, bellygall and irongall. The output of horngall amounts to 75 per cent of the total gallnut output. Gallnut is widely distributed in the mountainous and hilly areas of middle-southern China and is rich in hydrolysable vegetable tannins. The tannin content of horngall is $62-65$ per cent and 68 72 per cent for bellygall. The lowest tannin content is observed for flower gallnut, reaching 35 - 45 per cent. Chemically, the gallotannins are multiple esters of Dglucose with gallic acids. The gallnut is used directly as traditional Chinese medicine and industrially it is used for production of tannin acid and gallic acid as well as their derivatives. Recent annual output of gallnut in has been about 6,000 tons, one-third of which is exported mainly to Europe and Japan. The total income for the local farmers from collecting gallnuts is about 60 - 90 million yuan.

Tannic acid and gallic acid are the main products of the chemical processing of gallnut. More than ten processing plants have been built for the production of tannic acid and gallic acid with an annual output of 2-3,000 tons. The tannic acid is produced by the water extraction process, similar to that for the production of tannin extract. It is usually completed in a group of extractors in batches. In recent years a new, continuous level rotary extractor has been designed and used successfully in production of tannic acid in China. The advantage of this process is a high extraction rate of tannic acid (up to 99 per cent of its content in gallnuts). The quality of tannic acid for industrial use is standardised in GB $5308-85$ as shown in Table 16.

Tannic acid is used as a raw material for pharmaceutical production, the ink-making industry, enrichment of germanium, metal anti-corrosive and as drilling mud treatment agents. Specially treated tannic acid can be used in the beer industry as a clarifying agent.

The gallic acid is produced by acid or alkaline hydrolysis of tannic acid or of gallnut directly. It can also be hydrolysed by a special enzyme. The gallic acid is used for preparation of trimethoxy benzaldehyde, pyrogallic acid and other pharmaceutical intermediate products, as well as in the ink-making industry. Since the raw material for both tannic and gallic acid is gallnut, the total output of tannic and gallic acids is about $2-3,000$ tons annually while the individual output of each fluctuates depending on market demand.

\section{Forest Perfume Products}

The production of forest perfume products in China has a long history and plays an important role in the Chinese natural perfume industry. More than 100 plant species are used for production of essential oils and total output amounts to $15,000-20,000$ tons per year. The essential oils are also an important product for export and the annual export value totals about US $\$ 100$ million making up 8 - 10 per cent of total world trade of essential oils. About 40 per cent of these essential oils come from forest resources.

Some of the major production regions are based on the distribution of the plants used for extraction, e.g. linalool and Litsea cuvena oil in Fujian, eucalypt oil and cinnamon oil in Yunnan, Eucalyptus citriodora oil in Guangdong, star anise oil in Guangxi, cedarwood oil in Guizhou, and Cinnamomum oil in Jiangxi province. A series of technical developments has been introduced into the production process, such as highperformance distillation columns for effective separation of essential oil components and continuous extractors for solvent extraction. The application of super critical fluid extraction and molecular distillation is also under study. Efforts have been concentrated on the synthesis of new perfume products based on the components of essential oils. The annual output and exports of main forest essential oils are listed in Tables 17 and 18. 
Table 17. Annual Output of the Main Forest Essential Oils

\begin{tabular}{lc}
\hline Name of oil & Output (t) \\
\hline Cedarwood oil & $1000-1500$ \\
Cinnamomum camphora oil & 500 \\
C. camphora var. linaloolifer oil & 50 \\
C. longepaniculatum oil & $800-1200$ \\
C. parthenonylum oil & $500-1000$ \\
Cinnamon oil & $300-400$ \\
Eucalyptus. citriodora oil & $500-800$ \\
E. globulus oil & 1500 \\
Listea oil & $1500-2000$ \\
Star anise oil & $500-800$ \\
\hline
\end{tabular}

\section{Main Essential Oil Products}

\section{Litsea cubeba oil}

Litsea cubeba oil is a special essential oil, which is only produced in China from various Litsea species, such as L. cubeba, L. enosma and L. mollifolia. Litsea species are easily grown and widely distributed in the southern provinces of China, especially Hunan, Fujian and Sichuan. The essential oil is produced by steam distillation of the fruits and the oil yield is usually 3 4 per cent. The main component of the oil is citral, which makes up 60 - 80 per cent of the total amount of oil. The citral may be further purified by vacuum rectification. Litsea oil is used for production of citral, which is further used as a raw material for synthesis of ionone, methyl-ionone, as well as vitamins $\mathrm{A}$ and E. The oil is used directly in the food, cosmetic and tobacco industries.

\section{Eucalypt oil}

Eucalypt oil is produced by steam distillation of $E$. globulus, E. exserta and E. maideni leaves. The main component of eucalypt oil is cineole, which can also be produced from $C$. longepaniculatum leaves It is mainly used in common chemicals and medicine. The E. globulus oil with cineol content more than 70 per cent is used in various medicinal preparations. The industrial-grade eucalypt oil is also used for flotation in the mining industry.

\section{Eucalyptus citriodora oil}

E. citriodora oil is produced by steam distillation of E. citriodora leaves, which is mostly found in Guangdong and Guangxi provinces of China. Its main component is citronellal (65 - 80 per cent), citronellol, geraniol and their esters. E. citriodora oil is an important raw

Table 18. Export of some Forest Essential Oils, 1990 - 1991

\begin{tabular}{lcccc}
\hline & \multicolumn{2}{c}{1990} & & 1991 \\
& Quantity & Value & Quantity & Value \\
(tons) & US\$ m & US\$ m & 12.80 \\
\hline Cinnamon oil & 378 & 11.09 & 409 & 4.49 \\
Listea oil & 1038 & 8.83 & 793 & 12.76 \\
Eucalypt oil & 2354 & 13.03 & 2521 & 3.53 \\
Cedarwood oil & 1722 & 3.93 & 1103 & 4.96 \\
Star anise oil & 851 & 7.50 & 648 & 1.79 \\
E. citriodora oil & 454 & 1.26 & 459 & 2.20 \\
Natural camphor & 432 & 2.06 & 459 & 3.08 \\
C. parthenonylum oil & 1108 & 3.34 & 665 & 45.61 \\
\hline Total & 8337 & 51.04 & 7057 & \\
\hline
\end{tabular}


Table 19. Main Constituents of Essential Oil from Different Type of Camphora Trees (\%)

\begin{tabular}{lcccc}
\hline & $\begin{array}{c}\text { Camphor } \\
\text { type }\end{array}$ & $\begin{array}{c}\text { Linalool } \\
\text { type }\end{array}$ & $\begin{array}{c}\text { Cineole } \\
\text { type }\end{array}$ & $\begin{array}{c}\text { Isonerolidol } \\
\text { type }\end{array}$ \\
\hline Cineol & 1.17 & 0.13 & 50.00 & 0.03 \\
Camphor & 92.01 & 0.84 & 0.25 & 0.75 \\
Linalool & 0.53 & 92.10 & 2.03 & 16.05 \\
a-Terpineol & 2.87 & 0.22 & 14.35 & 0.03 \\
Safrole & 0.29 & 0.32 & 0.20 & 1.14 \\
Isonerolidol & - & 1.67 & - & 49.00 \\
\hline
\end{tabular}

material for the perfume industry and is used for isolation of citronellal and citronellol and for synthesis of hydroxyl-citronellol, ethyl ester of citronellol, menthol and some other perfume products. The oil is also directly used in soap and cosmetics, as well as for some medicinal preparations.

\section{Cinnamomum camphora oil}

Cinnamomum camphora oil is produced by steam distillation of the leaves, wood, root and fruit of Cinnamomum camphora, which contains 30 - 55 per cent camphor and safrole, cineole, terpineol, geraniol, etc. Natural camphor and a series of products, such as white camphor oil (rich in cineole), red camphor oil (rich in safrole) and blue camphor oil (rich in sesquiterpene), are obtained by the distillation process.

In recent years attention has been paid to the essential leaf oils, to ensure continuous supply without damage to trees. Studies have found that there is a wide variation in the chemical composition of $C$. camphora leaf oils. They can be divided into four groups: camphor-type, linalool-type, cineole-type and isonerolidol-type, according to their major components. The typical composition of these four oil types is shown in Table 19. Chinese scientists are now attempting to establish plantations of camphora trees with specific types of essential oil, to set up production bases for natural camphor, linalool and cineole.

\section{Star anise oil}

Star anise oil is produced from the fruit and leaves of Illicium verum by the process of distillation. They are mainly found in Guangxi. Although the oil yield from the fruit is much higher than from the leaves, oil production basically uses the leaf as raw material because of lower costs. Commercially, five grades of star anise oil are identified according to their anethole content. It is mainly used in the food and alcohol industry, as well as for some pharmaceutical prepara- tions. The anethole can also be a base material for the synthesis of anisaldehyde, anisonitrile, anisic acid.

\section{Cedarwood oil}

Cedarwood oil is produced from the wood, sawdust and root of Cupressus funebris mainly in the provinces of Guizhou and Sichuan. The oil yield is $2-6$ per cent of the wood. Its main components are cedrol (30 - 40 per cent), cedrene and terpineol. Cedarwood oil is used for the preparation of cedrol and cedrene, which may be further processed to obtain methyl ether, isopropyl ether and cedryl acetate, cedranone, etc. The essential oils and the reprocessed products are used in the perfume and medicinal industries.

\section{Cinnamon oil}

Cinnamon oil, an important exported perfume product, which is produced from the leaves, bark, fruits and roots of Cinnamomum cassia. Its main distribution area is Guangdong and Guangxi. The cinnamon oil is rich in cinnamaldehyde ( 80 - 95 per cent) and the other components are cinnamyl acetate, salicylaldehyde, eugenol, vanilin and benzyl aldehyde.

\section{Forest Medicinal and Health Products}

China is well known for its long history and the associated accumulated knowledge of the medicinal use of plants which forms Chinese traditional medicine. Numerous Chinese herbs have been recorded in pharmacopoeias and medicinal books. In this paper, only the medicinal and health products extracted and purified from medicinal forest plants are discussed. With the development of phytochemistry and advanced analytical techniques, the study of the effective components of medicinal plants has made a great contribution to the pharmaceutical industry to produce many new medicines for the treatment of various diseases. 


\section{Ginkgo biloba extract}

Ginkgo biloba is an important economic tree species in China and is widely distributed in the central part of the country. Its leaves contain a series of flavonoid glycosides and lactone-ginkgolides and bilobalide, which are biologically active substances and could be used for the improvement of cerebral and peripheral blood circulation. Several factories have been built for production of the Ginkgo biloba extract with the quality standard of flavonoids $\geq 24$ per cent and ginkgolides $\geq 6$ per cent. A series of pharmaceutical and health preparations such as oral liquids, capsules and instant extracts have appeared in the Chinese market. The comprehensive utilisation of ginkgo trees, including nuts and leaves, provides great economic benefits to the local farmers. The ginkgo leaves are also exported at the price about US\$1,000 per ton.

\section{Saponins from Gynostemma pentaphyllum}

Gynostemma pentaphyllum is an understorey plant in forests and is widely distributed and planted in the central part of China. Its active components are triterpeneglycosides, with a structure similar to those of Ginseng, which may be used for reducing triglycerides in blood and improving the blood circulation for patients with high blood viscosity. Several facilities have been built for its production. The pharmaceutical preparation of saponins has been approved by the Chinese Ministry of Health.

\section{Sea buckthorn products}

Sea buckthorn is a wild shrub distributed widely in the north-east and north-west parts of China, with a total area over 1 million ha. The main species is Hippophae rhamnoides subsp. sinensis and its fruit is rich in nutritive and medicinal components. A series of sea buckthorn products, such as juice, drinks, flavonoids and oils are produced. Over 150 processing plants have been built to produce a series of products, among which the sea buckthorn oil is the most important for medicinal use. The oil is produced from the meat and seed of the fruit by pressing or solvent extraction. The oil is rich in unsaturated fatty acids and a series of biologically active components, e.g. Vitamin E, carotenoids, sterols and amyrins. In clinics the oil is used for treatment of skin burns, X-radiation burns and gastric ulcers, etc.

\section{Aralia saponins}

Aralia saponins are made from the leaves of Aralia decaisneana and A. chinensis, which are found in the central part of China. Its main active components are the triterpenoid saponins-glycosides with the oleanolic acid as the aglycone. Pharmacological studies show that the saponins may raise the resistance of test rats to fatigue, low temperature and oxygen deficiency. The saponins, oleanolic acid as well as oral liquids and health drinks, have been made from the Aralia leaves and flowers. Oleanolic acid is used to treat hepatitis.

\section{Acanthopanax extract}

Acanthopanax extract is produced by alcohol extraction from damaged roots and stems of Acanthopanax senticosus, which is mainly distributed in north-east China. The extract is rich in saponins, phenolic glycosides and coumarins, which produce a sedative effect and are used for neurasthenia and bronchitis.

\section{Berberine from Phellodedron}

Phellodedron amurese is a species of the family Rutaceae, which is distributed in forest areas of northeast China. Its bark is rich in berberine alkaloids, and possesses strong anti-bacterial properties. The berberine from the $P$. amurese bark is extracted by acid-water extraction and further purification of the extract is conducted by adjusting the $\mathrm{pH}$. Finally, the berberine is crystallised from 70 per cent EtOH solution. It is widely used in clinics for bacillary dysentery and inflammatory diseases.

The technology for production of active components from forest medicinal plants mainly consists of two processes; extraction and purification. For the extraction process, usually water or alcohol is used with a special extractor, with further purification by other processes, such as liquid extraction, chemical treatment, precipitation, absorption with various resins (macroporous absorption resins, ion-exchange resin, etc.) and crystallisation.

The purified product is sold as the base medicine to pharmaceutical companies, which produce the various preparations after approval by the Ministry of Health or related authorities. 


\section{Conclusion and Prospects}

Chemical utilisation of NWFPs has developed in China for many years. With the encouragement and support of the Chinese Government, it now is an important part of the forest product industry and covers more than 1,000 factories with different production capacities, employing more than 100,000 workers without counting jobs in the production of raw material. It produces a variety of products, which are successfully used in many industries. The value of output is more than two billion yuan annually. Many products are also exported and hold an important position in the world market.

China is a vast country with a wide variety of climatic environments as well as plant species. Furthermore, it is also a developing country with relatively rich and cheap labour resources. The utilisation of NWFPs is especially important, to generate more benefits to the local government and people. For example, in a number of counties in China, rosin production is the main industry and it provides the major part of the financial incomes to the county.

Chemical utilisation of NWFPs usually is valueadded, industrial utilisation requiring more complex technology and equipment than other forest uses. For development of the chemical utilisation of NWFPs,
China has already accumulated much experience in organisation and administration, research and development, design, education, production and marketing. Only continued enhancement of the research and development of new products and technology, exploration and utilisation of new NWFP resources and rational management and protection of the natural resources or cultivation of the plant, can promote the growth of this industry and thus finally deliver economic benefit to the poor mountain and forest areas.

The development of chemical NWFPs is also closely linked to international trade and markets. Since ecological and geographical conditions vary between countries, the products are of international significance. For example, rosin, tannic acid, gallic acid, essential oils and their by-products, which are produced in China, are exported in large amounts. The expansion of international linkages and exchange of information, technological achievements between scientists, as well as the establishment of co-operation with various international organisations, is necessary.

Non-wood forest resources are renewable natural resources. Development of fine chemical products from these resources would not be disturbed by a "resources crisis" and could have promising prospects on the basis of continuous efforts in research and development, technical progress and marketing.

\section{References}

Chemistry and Industry of Forest Products. 1994. Special issue on reprocessing of rosin and turpentine. Vol. 14. Chen, D., Y. He and A.G. Brown (eds.) 1992. Forest Chemical Industry and Products. Publishing House of Chemical Industry, Beijing.

Chinese Forestry Year Book. 1986 - 1992. Publishing House of Chinese Forestry, Beijing.

Collection of Chinese Forestry Standards. 1992. Publishing House of Forestry, Beijing.

Ho, G. and A.G. Brown (eds.). 1992. Black Wattle Tree and Its Utilisation. Publishing House of Chinese Forestry, Beijing.

Lik. 1993. Flavour Fragrance Cosmetic. Review of Chinese Perfume Industry in 1991 1: 17-26.

Proceedings of International Symposium on Chemistry and Utilization of Tree Extractives, Nanjing, 1990.

Proceedings of National Symposium on Chemistry and Utilization of Tree Extractives, Nanjing, 1986.

Proceedings of National Symposium on Gum Oleoresin, Wuzhou, Guangxi, 1992.

Song, Z. 1994. Development of fine chemicals from Chinese gum oleoresin, Chemistry and Industry of Forest Products 14(1): 67-74.

Sun, D. 1993. Recent advances of chemistry of vegetable tannins and techniques of tannin extract production. Chemistry and Industry of Forest Products 13(4): 339-343.

Ye, H. 1994. Production and development of essential oils for perfumes and fragrances based on forest resources. Journal of Chemical Industry of Forest Products 28(5): 43-46.

Zhang, Z. 1992. Investigation and application of new technology of continuous extraction of gallnuts. Chemistry and Industry of Forest Products 12(3): 179-182. 


\section{Annex 1}

\section{Brief Introduction to the Research Institute of Chemical Processing and Utilization of Forest Products (RICPUFP)}

The Research Institute of Chemical Processing and Utilization of Forest Products is an institution under the Chinese Academy of Forestry. Since its establishment in 1960, the Institute has been developed as the national centre, carrying out basic and applied research, product development, chemical engineering and design in the fields of chemistry, chemical processing and utilisation of forest products, both wood and non-wood forest products. The Institute is accredited by the Ministry of Education and the Ministry of Forestry to award Masters and Doctoral degrees, as well as a post-doctoral centre of Forest Product Engineering.

The main research directions of the Institute are:

* Chemical utilisation of wood, including wood pulping, wood hydrolysis and furfural, wood energy, active carbon and carbonaceous absorbent materials.

* Chemical utilisation of non-wood forest resources, including rosin, turpentine, plant polyphenols and their by-products, essential oils, natural pigments, medicine and other natural organic products from the forest.

* Wood adhesives

The Institute is based at Nanjing and comprises nine research departments: naval stores, wood pulping, wood hydrolysis, carbonaceous absorbent material, natural tannins, biological active substances, wood adhesives, chemical engineering and equipment and information, and a design institute for the forest chemical industry. A National Technical Centre of forest chemical engineering is now under construction in the Institute, which will be provided with pilot-study facilities.

The total staff of RICPUFP is 302 employees, including 15 research professors, 80 associate professors and senior engineers and 90 engineers. Since its foundation, RICPUFP has completed more than 200 research projects and most have already been applied in industry. The scientific and technical achievements have been introduced to over 200 enterprises in 27 provinces of the country. 


\section{Annex 2 \\ Directory of Main Enterprises and Products}

\section{Enterprises}

Wuzhou Rosin Plant

Guilin Chemical Plant

Yanyuan Rosin Plant

China Golden Dragon Group

Deqing Forest Chemical Plant

Qinxi Country Rosin Plant

Fengkai Forest Industry Co.

Nanfeng County Rosin Plant

Xinyi Rosin Plant

Yalkeshi Tannin Extract Plant

Wuming Tannin Extract Plant

Daxian County Tannin Extract Plant

Zhushan Forest Chemical Plant

Jiangxi Camphor Plant

Jiange Forest Chemical Plant

Baoshan 701 Plant

Lianyuanggang Xugou Forest

Chemical Plant

Affiliated plant in RICPUFP Pure

Shellac plant

\section{Products}

Rosin, turpentine, disproportionated rosin, linalool, a-pinene, synthetic camphor

Rosin, turpentine, polymerised rosin, borneol

Rosin, turpentine, polyterpene resin

Rosin, turpentine, various processed products from rosin and turpentine

Rosin, turpentine, rosin esters, from rosin and turpentine, synthetic camphor

Rosin, turpentine, modified rosin resins

Rosin, turpentine, polyterpene resins, maleated rosin

Rosin, turpentine, rosin resins, pine oil, longifolene

Rosin, turpentine

Larch bark tannin extract

Tannin extract

Tannin extract

Tannin acid, gallic acid, trimethoxy-benzaldehyde

Eucalypt oils, natural camphor, dipentene

Cedarwood oil, cedrol

Eucalypt oil, shellac

Pine needle powder, pine needle extract, granular feeder

Rosin ester, Ginkgo biloba extract, shellac, bleached shellac 